\title{
Preaching Rhetorical Invention: Poeta and Paul in the Digby Conversion of St Paul
}

This article evaluates the Digby Conversion of St Paul through the lens that medieval preaching affords, exposing how Poeta's rhetoric makes the internal process of Paul's conversion external and transparent to the audience. By uncovering Poeta's incorporation of preaching strategies and the rhetorical principle of invention specifically, I show how Poeta's prologues and epilogues grant Paul the ethical mobility he requires to become a believable Christian convert and preacher. Poeta's rhetoric anticipates and validates the language of Paul's sermon, a circumstance that prompts my reevaluation of Poeta's role as a framing device to show instead his interactive relationship with Paul throughout the play.

The late medieval saint play known as the Digby Conversion of St Pauldramatizes the transformation of its titular character from persecutor of Christians to Christian convert and preacher. ${ }^{1}$ The success of Paul as a preacher, and consequently of the play as a didactic medium, depends upon the believability of Paul's changed character because, after repenting, Paul must preach convincingly about his own experience of sin. Paul's preaching reminds the audience that he himself was a sinner and, by revisiting his vice in his sermon, Paul introduces the potential to question the sincerity of his turn towards virtue. To ease concerns about the legitimacy of his conversion, Paul's internal transition requires external representation, and so, as Sarah Salih explains, St Paul 'takes on the difficult, but imperative, task of finding and staging an exterior sign of the interior experience of contemplation'. ${ }^{2}$ Salih identifies the external marker of Paul's conversion as his change of clothing: ${ }^{3}$ he discards the attire of 'an aunterous knyth' for 'dyscyplys wede' (sd 14, sd 502). ${ }^{4}$ Scholars also discuss Paul's change of name from Saul as a second external marker. ${ }^{5}$ These conventions surely reflect Paul's internal change, but, as I

Ann Hubert (ahubert2@illinois.edu) is a doctoral student in the department of English at the University of Illinois at Urbana-Champaign. 
will argue, Paul's preaching is an even more substantial representation of this externalizing process. The sermon in the last part of this play rhetorically transforms the sin staged in the first part, replacing Saul's proud, bombastic boasts as persecutor with Paul's humble directives as preacher. Since Saul's sin and Paul's repentance are themselves rhetorically constituted, the sermon itself is the crucial external indicator of Paul's alteration because it reconfigures his once self-absorbed rhetoric into a tool that announces the Lord. Linguistically conveying Paul's error in desiring to serve himself instead of God, Paul's sermon broadcasts the power and persuasion of his divinely redirected rhetoric, firmly situating his conversion in the medieval arts of preaching.

In The Conversion of St Paul, the figure essential for an interrogation of the playwright's connection between Paul and preaching rhetoric is Poeta. Poeta divides the action of the play into three parts, promising the audience episodes of Saul in Jerusalem, his conversion en route to Damascus, and his apostolic work as Paul in Damascus. In each of these episodes, Poeta offers the audience interpretative guidance, subtly incorporating elements of preaching language into his addresses in order to anticipate and clarify the rhetorical nature of Paul's conversion. By demystifying Paul's conversion and sermon, Poeta's discourse demonstrates St Paul's extensive engagement with the preaching tradition, not only in Paul's delivery of a thematic sermon, a popular form of preaching contemporaneous with the play, ${ }^{6}$ but also, and more importantly, through his deployment of the rhetorical principle of inventio (invention). ${ }^{7}$

Rhetorical invention concerns 'finding' the material on which one is to discourse, and, in the case of the medieval preacher, invention means selecting the subject matter of and supporting evidence for his sermon; in St Paul, this subject matter and evidence are the three episodes from Paul's life as persecutor, convert, and preacher. Taking advantage of the range that rhetorical invention affords, Poeta moves over the course of the play from an indirect approach, in which he leaves interpretation open to his audience, to a direct approach, in which he makes the signification of events explicit for the audience. This movement in rhetorical invention parallels the play's progressive re-representation of Saul/Paul in concert with his self-awareness: from a characterization that is consistent with his initial self-identification (persecutor of Christians) to one that negates or empties that formerly boastful self (Christian convert) to one that proclaims the meaning of conversion and selfhood (Christian preacher). Poeta's engagement with inventio imposes a rhetorical framework on the play's three episodes, creating a meta-rhetorical preaching 
commentary that drives the play and encapsulates Paul as an exemplum throughout, the three stages of his developing character illustrating the literal, allegorical, and tropological levels of scriptural interpretation in a medieval sermon. Both Poeta (in his meta-rhetorical commentary) and Paul (in his sermon) develop these three meanings to mark Paul's internal conversion externally. Through his incorporation of inventio and interpretative levels, Poeta exposes the cognitive process of Paul's sermon, making the structure of Paul's preaching language - that is, the rhetoric representing his shift as Christian convert - transparent and accessible to the audience.

By considering Poeta's and Paul's complementary engagement with these three levels of scriptural interpretation, this article illustrates how St Paul's preaching rhetoric places Poeta and Paul in dialogue with each other. This connection reevaluates Poeta's role as a framing structure for the drama's presentation, ${ }^{8}$ emphasizing instead his interactive relationship with Paul. As I will show, St Paul's use of rhetorical invention effects a transformation in Poeta as the play progresses, switching his purpose from an unassuming expositor to a forceful practitioner of preaching rhetoric, that is, from a preacher who employs an indirect approach to one who employs a direct approach. This alteration in Poeta parallels the change that Paul as convert undergoes, reinforcing Poeta's and Paul's scriptural interpretations at the additional level of the play's form. Enhancing its thematic content with its form, St Paul employs Poeta's preaching rhetoric not only to grant Paul the ethical mobility he requires to become a Christian preacher but also to validate the salvific message of his sermon.

\section{Poeta and Rhetorical Invention}

Poeta introduces and concludes each of St Paul's three episodes, ${ }^{9}$ and his engagement with sermon rhetoric is immediate. Opening the play with a two-stanza speech, Poeta employs such preaching strategies as an invocation and prayer for the audience's well-being in the first stanza. He then discusses rhetorical interpretation in the second stanza:

Rex glorie, kyng omnipotent, ${ }^{10}$

Redemer of pe world by thy pouer diuine,

And Maria, pat pure vyrgy[n] quene most excellent,

Wyche bare pat blyssyd babe Jhesu pat for vs sufferd payne,

Vnto whoys goodnes I do inclyne, 
Besechyng pat Lord, of hys pytous influens,

To preserue and gouerne thys wyrshypfull audyens.

Honorable frendys, besechyng yow of lycens

To procede owur processe, we may [shew] vnder your correccyon,

The conuersyon of Seynt Paule, as pe Byble gyf experyens.

Whoo lyst to rede pe booke Actum Appostolorum, ${ }^{11}$

Ther shall he haue pe very notycyon;

But, as we can, we shall vs redres,

Brefly, wyth yowur fauour, begynyng owur proces.

Poeta positions himself in a complex relationship to the audience by the end of the second stanza. His initial appellative tag, 'Honorable frendys', and use of the verb 'beseech', following the articulation of prayer in the first stanza, echo the opening address a preacher would employ in a sermon. ${ }^{12}$ The word 'processe' further confirms that Poeta's language is within the presentational scope of sermon-making $(9,14)$ : 'process' is a word that writers of medieval sermon manuals and preachers often used to refer to the parts of a sermon, both in Latin and the vernacular. ${ }^{13}$ Despite his incorporation of preaching rhetoric in these stanzas, Poeta is not yet ready to assume an authoritative preaching persona, as is immediately evident in his generous bequeathing of power: the audience's 'lycens' and 'correccyon' drive the presentation of this play (8-9). Poeta's deference is certainly gratuitous, but the reality of his actual need to cater to the audience's whims surfaces before the first episode ends, when the marginal note 'Poeta-si placet' makes Poeta's function as epilogue optional (sd 155); Poeta should return to the stage only if it is pleasing, or necessary, for the audience in a particular performance. Poeta's responsibility, as the play's orchestrator, is to gauge audience reaction and appease audience desires, a responsibility that makes Poeta a mediator not only between play performance and audience but also between the interpretative moves of the audience and the playwright. To compose his play, the St Paul playwright inevitably made decisions about which material from the bible, and specifically from the Acts of the Apostles, to dramatize. By calling attention to the audience's 'lycens' and 'correccyon', Poeta empowers the audience to critique the playwright's selections, suggesting that the spectators' interpretative command of scripture as a source of 'experyens' and 'notycyon' is more reliable than the players' $(8-10,12)$. Scripture is a resource that enables the audience to correct the shortcomings of the play for which Poeta is already apologizing: 'we shall vs redres' (13). Poeta's mediation between the play and 
audience betrays the tension that the selection of biblical material for dramatic presentation creates, a tension that Poeta seeks to mitigate by locating the interpretative power of Acts in the audience.

In his next appearance, which, as I have noted above, is made optional in the margins of the manuscript, Poeta closes the first episode by again catering to the authority of the audience:

Fynally, of pis stac[y]on thus we mak a conclusyon.

Besechyng thys audyens to folow and succede

Wyth all your delygens pis generall processyon;

To vnderstande pis matter, wo lyst to rede

The Holy Bybyll for pe better spede,

Ther shall he haue pe perfyth intellygens,

And pus we comyt yow to Crystys magnyfycens!

Poeta defers, for a second time, any interpretative control of the first episode as it has unfolded, and relies instead on the audience to refer to the bible to attain the 'perfyth intellygens' of the episode's meaning (160). Poeta does not need to offer the audience any analysis, however, because at the end of the first episode, Saul's character is internally consistent, his power and position as persecutor remaining unchanged:

My pere on lyue I trow ys nott found!

Thorow pe world, fro pe oryent to pe occydent,

My fame ys best knowyn vndyr pe fyrmament!

I am most drad of pepull vnyuersall.

The first episode therefore grants the audience interpretative control when the presentation of Saul presents nothing over which to squabble.

Poeta's presence in the first episode underscores the condition of effective rhetoric, that is, to be so well constructed that the moves it makes go unnoticed by an audience. Poeta is employing a branch of rhetorical invention known as insinuatio (insinuation), or the indirect approach, whereby he lets the audience draw its own conclusions from the material he presents: 'Insinuation is an address which by dissimulation and indirection unobtrusively steals into the mind of the auditor. ${ }^{14}$ By employing insinuatio, the playwright positions Poeta as a meta-preacher - the ultimate interpretative source for the meta-rhetorical commentary that the play is constructing without detracting from the illusion he has created that the audience possesses interpretative control over this episode. Poeta's indirect approach underscores 
that his Saul exemplum requires no explanation: at the literal level of scriptural interpretation, Saul is a proud persecutor, exactly what this episode conveys. Bracketing the first episode with Poeta allows the playwright to contextualize Saul's character rhetorically and visually against Poeta: Poeta's humility and deference as preacher strongly contrast with Saul's proud and abrasive language as persecutor. An example to his audience in both word and deed, ${ }^{15}$ Poeta anticipates what Saul himself will become as a preacher after his conversion, and so Poeta becomes the template through which Saul's conversion to preacher can be understood. That template materializes through the playwright's choice to create the greatest possible contrast between Poeta and Saul in this initial episode.

Poeta reinforces his role as meta-preacher by opening the second episode of St Paul's tripartite structure with the repetition of the appellative tag 'Honorable frendys', the verb 'beseech', the attention to the play's 'prosses', and the plea for the audience to grant 'lycens' (162-4):

Honorable frendys, we beseche yow of audyens

To here our intencyon, and also our prosses.

Vpon our matter, be your fauorable lycens,

Another part of pe story we wyll redres:

Here shalbe brefly shewyd, wyth all our besynes,

At thys pagent Saynt Poullys conuercyon.

Take ye good hede, and therto gyf affeccyon!

Poeta takes a slightly more authoritative tone when he concludes this stanza, however, commanding the audience to pay attention to the action to come'Take ye good hede' - and to view it with 'affeccyon'. By telling the members of the audience to invest emotionally, Poeta is advising them to be moved by the story rather than to view it at a remove, rationally assessing its fidelity to the bible and Acts. (Significantly, Poeta no longer mentions the play's sources in this stanza.) Creating an emotional response to alter an audience's course of action is one of the offices of rhetoric; indeed, it is also one of the markers of a sermon's efficacy. ${ }^{16}$ Poeta's request for an affective response demonstrates that he has begun to shift the burden of interpretative control from the audience to himself; it also highlights how his use of rhetorical invention is changing from an indirect to a more direct approach of interpretation, wherein Poeta will assist the audience's understanding of the scene played before it. Poeta's interpretative assistance is increasingly necessary because, in the second episode, Saul's character becomes internally inconsistent when 
he converts and receives baptism. Through his assistance, Poeta aligns the audience with Paul by asking it to relinquish its claim to interpretative control, an idea that complements how Saul's self-control is suspended when God both cripples and blinds him during his conversion (198-9). Through Poeta's guidance, the audience therefore experiences a sort of internal and contemplative transition even as the play stages Saul's own religious conversion. Saul's transformation informs the first of two stanzas that Poeta delivers to conclude the second episode of the play:

Thus Saule ys conuertyd, as ye se expres,

The very trw seruant of our Lord Jhesu.

Non may be lyke to hys perfyzt holynes,

So nobyll a doctor, constant and trwe;

Aftyr hys conuersyon neuer mutable, but styll insue

The lawys of God to teche euer more and more,

As Holy Scrypture tellyth whoso lyst to loke perfore. (346-52)

The proliferation of adjectives — 'very trw', 'perfy3t', 'nobyll', and 'constant and trwe' - that Poeta uses to insist that Saul was 'neuer mutable ... [a]ftyr hys conuersyon' draws attention to Saul's very mutability, ${ }^{17}$ as well as to the subsequent need for Poeta to assist the audience's interpretation of the Saul exemplum in this episode. Because of his conversion, Saul inhabits a new Christian identity with new-found humility, a humility which not only recalls Poeta's meta-rhetorical posturing but also allegorically replicates Christ's humility. Caught somewhere between the indirect and the direct approach of rhetorical invention, Poeta, of course, does not overtly announce this allegorical level of scriptural interpretation to the audience in his first concluding stanza. What he does say is that 'Holy Scrypture tellyth whoso lyst to loke'. But Poeta's directive to consult scripture differs from the first episode: Poeta does not suggest that the play should continue to 'proced ... vnder [the] correccyon' of the audience members or that they should interpret the action they have just seen; rather, he assigns this task to those 'pat letteryd be', 18 as the second stanza (cited below) concluding this episode reveals (8, 355). While the referent of the relative clause 'pat letteryd be' does not necessarily exclude the members of the audience, Poeta's rhetoric certainly does not immediately include them: ${ }^{19}$ 
Thus we comyte yow all to pe Trynyte,

Conkludyng thys stacyon as we can or may,

Vnder pe correccyon of them pat letteryd be;

Howbeyt vnable, as I dare speke or say,

The compyler hereof shuld translat veray

So holy a story, but wyth fauorable correccyon

Of my honorable masters, of per benynge supplexion.

(353-9, my emphasis)

By asking for those who are 'letteryd', Poeta invokes the need for a qualified interpreter, and, as a result, calls attention to the process of selection requiring a 'compyler' who 'shuld translat'. Thus, Poeta again addresses inventio in the construction of this 'So holy a story': collection and selection are typical processes of invention for medieval 'compilers' and 'translators'. Indeed, the playwright demonstrates great skill in the selection of his material for this episode, integrating three disparate accounts of Saul's conversion found in the Acts of the Apostles into one cogent story-line for his drama. ${ }^{20}$ Even in spite of the playwright's skill, Poeta insists that the 'correccyon / Of ... honorable masters' is necessary, and the master whom the playwright includes in his play and intends the audience to look towards is Poeta.

The playwright's presentation of Poeta and the role that Poeta fulfils alters yet again as the third episode of St Paul begins. Here, Poeta sheds his unassuming role of orchestrator for that of a decisive preacher just as Saul discards his knight's regalia for disciple's weeds:

The myght of the Fadirys potenciall Deite

Preserue thys honorable and wurshypfull congregacyon,

That here be present of hye and low degre,

To vnderstond thys pagent at thys lytyll stacyon,

Whych we shall procede wyth all our delectac[y]on,

Yf yt wyll plese yow to gyf audyens fauorable.

Hark wysely therto - yt ys good and profetable!

$(360-6)$

Poeta now transforms the 'Honorable frendys' $(7,162)$ to whom he spoke in the previous two prologues into an 'honorable and wurshypfull congregacyon', and the audience that was once educated enough to make its own interpretations suddenly fractures into persons of 'hye and low degre', confirming the differentiation that Poeta's earlier reference to those who are 'letteryd' signalled (355). ${ }^{21}$ Poeta commands the audience's attention in this 
episode, employing the direct approach of rhetorical invention to present himself as the one who must command the audience if it is to understand the material before it. Demanding his audience's attention with an invocation of God's might and a prayer, Poeta transforms his role as mediator between audience and playwright, becoming instead mediator between the audience and God. Poeta conveys the 'myght of the Fadirys potenciall Deite' to the audience (360); Poeta facilitates the audience's ability to understand theologically the content of the play before it; Poeta anticipates the position in which Paul, as converted preacher, will imminently present himself. At the outset of this episode, Poeta's mediation expands to include a moral responsibility, and so he addresses the tropological level of scriptural interpretation that is the preacher's primary concern in a sermon. Poeta therefore portrays Paul as an exemplum of moral righteousness in the third episode, as one of a series of preachers, including Poeta, who act in the image of Christ, preaching to the faithful, and whom the members of the audience should strive to imitate.

The role of meta-preacher that Poeta inhabits becomes obvious when he closes the third episode after Paul delivers his sermon. In the first of two stanzas at the end of the play, Poeta cites Latin as a preacher would in order to confirm his point:

Thus leve we Saule wythin pe cyte,

The gatys kep by commandment of Caypha and Anna;

But the dyscyplys in pe nyzt ouer pe wall truly,

As the Bybull sayeth: 'dim[i] serunt eum summitten[te]s in sporta'. ${ }^{22}$

And Saule, after that, in Jerusalem vera, ${ }^{23}$

Joyned hymself and ther accompenyed

Wyth pe dyscyplys wher pei were vnfayned.

Poeta no longer tells the members of the audience to refer to the bible; rather, he does so himself by citing Acts 9:25. Thus Poeta again aligns the audience with Paul, placing it in a situation where it must humbly accept the Lord just like Paul, who graciously accedes to be the Lord's servant. Furthermore, Poeta oversees the audience's interpretation of the play through his concluding directive to sing a hymn:

Thys lytyll pagent thus conclud we

As we can, lackyng lytturall scyens,

Besechyng yow all, of hye and low degre, 
Owur sympylnes to hold excusyd and lycens,

That of retoryk haue non intellygens,

Commyttyng yow all to owur Lord Jhesus,

To whoys lawd ye syng: 'Exultet celum laudibus!' 24

The hymn in which Poeta leads the audience invokes the setting of a mass and is an 'appropriate hymn since in the Sarum rite it was used in the Office of the Conversion and Commemoration of St Paul'. ${ }^{25}$ This hymn, in conjunction with the exposition Poeta offers in the previous stanza, places the spiritual conclusion and understanding of the play firmly in his interpretation. Poeta no longer appeals to the audience, nor does he make his opinion subsidiary to the audience's interpretation.

Poeta must assume the role of an outright preacher in the final episode because Paul's character is now internally different, a difference that Paul's change of clothing signals externally. Paul is not a persecutor of Christians any longer, but a Christian himself, and Poeta's concluding biblical citation and hymn convey this authoritative interpretation of Paul's transformation to the audience. Poeta also mentions in his concluding stanzas that Paul goes on to join the disciples in Jerusalem 'wher pei were vnfayned', or undisguised (655). The company Paul will keep is an additional external indicator confirming his internal change. Poeta's direct approach encourages and eases the understanding of Paul's new identity, and importantly, does so without competing with Paul as preacher. Poeta therefore concludes the play by reinforcing the meekness that Paul's preaching conveys, highlighting the players' 'lackyng lytturall scyens', or knowledge of Latin, their 'sympylness', and their little 'intellygens ... of retoryk' $(657,659,660)$. Despite his insistence to the contrary, Poeta certainly has demonstrated that he and the other actors know some Latin (at least enough to quote it) and that the play's engagement with rhetoric is more than cursory, as the repeated deployment of inventio confirms. Poeta's humility in this concluding stanza therefore reinforces the consistency of his character, significantly displaying for a second time the template of humility through which the audience can comprehend Paul's transformation into preacher. By emphasizing humility, Poeta draws attention to the mechanism through which the audience can judge the play's didactic success, showing that God's grace becomes available to an audience through the preacher's rhetorical strategies, including those strategies informing Poeta's stanzas and Paul's sermon on the seven deadly sins in the play's third episode. Poeta's humility in the concluding stanza 
also underscores what Paul as preacher has learned, a topic I will discuss in the section below. By engaging the audience in the rhetorical process of sermon construction throughout St Paul, Poeta marks the rhetorical shift that Paul undergoes during his conversion externally, and this transparency lends Paul's conversion and ensuing sermon credibility.

\section{Paul the Preacher}

The persuasive success of Paul's sermon derives from Poeta's role as metapreacher and practitioner of inventio in the prologues and epilogues to each episode. Indeed, the sermon that Paul delivers gains rhetorical power and momentum not only from Poeta but also from its development in the style of a thematic sermon, an outline of which I provide in appendix $1 .{ }^{26}$ The beginning of Paul's sermon addresses the Lord and invokes a prayer first for the audience's well-being — 'Saue pis asemly' — and then for himself (502, 504):

That Lord pat ys shaper of see and of sonde,

And hath wrow3t wyth hys worde al thyng at hys wyl,

Saue pis asemly pat here syttyth or stond,

For hys meke mercy, pat we do not spyll.

Graunte me, good Lorde, pi pleasure to fulfyll,

And send me soch spech pat I the truth say,

My ententyons profytable to meve yf I may.

Paul prays for 'spech' that will effectively convey the word of the Lord to his audience, demonstrating rhetorically that he has emptied himself of his former pride and is now merely a vehicle for expressing truth. Hoping to fulfill the Lord's pleasure by acting as his servant and mediator, Paul emphasizes in his prayer the change that his character undergoes from the beginning of the play: Paul desires to 'say ... the truth' instead of persecuting those who speak the truth, and he wants to say it with 'ententyons profytable to meve' the audience. Paul's rhetoric therefore echoes that of Poeta's prologues, both in form — addressing the audience and praying for it — and in intention: like Poeta, Paul situates himself as a mediator, between the audience and God, who produces an affective response in his auditors. Paul's desire 'to meve' his audience announces the moral intention of his sermon, making the alteration of the audience's behaviour through the consideration of his rhetoric the explicit goal of his preaching. 
After he has established himself as a willing vessel conveying God's message, Paul proceeds to his sermon proper, addressing the audience as 'Welbelovyd fryndys', and identifying 'Pryde' as the theme of his sermon on the seven deadly sins $(509,511)$ :

Welbelovyd fryndys, per be seuen mortal synnys,

Whych be provyd pryncypall and pryncys of poysons.

Pryde, pat of bytternes all bale begynnys,

Wythholdyng all fayth, yt fedyth and foysonnys,

As Holy Scrypture baryth playn wytnes:

'Initium omnium peccatorum su[per] bia est'-27

That often dystroyth both man and best.

Off all vyces and foly, pryde ys the roote;

Humylyte may not rayn ner yet indure.

Pyte, alak, that ys flower and boot,

Ys exylyd wher pryde hath socour.

'Omnis qui se exaltat humiliabitur'. ${ }^{28}$

Good Lord, gyf vs grace to vnderstond and perseuer,

Thys wurd, as pou bydyst, to fulfyll euer. (509-22)

In the first of these stanzas, Paul confirms the theme of his sermon through a Latin citation from Eccles. 10:13. This authority incorporates the word of his theme, 'su[per]bia', or pride, a standard practice in late medieval sermonmaking. ${ }^{29}$ After identifying his theme, Paul moves directly into a protheme that establishes pride's place as the foremost vice on the tree of vices. The protheme further develops the concept of pride by describing its antidote, humility. Paul confirms the assertion of his protheme by citing another biblical authority, this time from Luke 14:11 and 18:14. This strategy of describing a vice through its opposing virtue highlights the damning effects of pride through humility's restorative quality, a concept that Paul's personal experience of being crippled and blinded before his conversion underscores. Paul then concludes this section of his sermon with a brief prayer to the Lord and an invocation of grace for the audience, both standard components of sermon prothemes (521-2). ${ }^{30}$ Throughout the opening stanzas of his sermon, Paul discusses his humility, and, in not claiming any authority apart from God's, he shows the meekness that proves his conversion from his former pride. Paul has become a Christian preacher, unified in word and deed, a conversion that Poeta's meta-rhetorical posturing anticipated in the first episode. 
Paul next restates 'pryde' as his theme and moves immediately to the first division of his sermon (523). This and each of the ensuing two divisions return to the subject of the sermon's theme and protheme in order to explicate pride and humility through presentations of personal experience with sin. Paul continues to incorporate language evoking the metaphor of the tree of vices throughout his divisions, a move that strengthens the overall delivery of his sermon by lending it continuity. Paul's own personal experience of humbling meekness is the topic of the first division, which a biblical citation from Rom. 11:20 confirms:

Whoso in pryde beryth hym to hye,

Wyth mysheff shalbe mekyd as I mak mensyon.

And I therfor assent and fully certyfy

In text, as I tell the trw entencyon

Of perfy3t goodnes and very locucyon:

'Noli tibi dico in altum sapere sed time'. ${ }^{31}$

Thys ys my consell: bere the not to hye!

Paul locates his personal experience with pride in the bible, explicating via scripture both himself and the actions that the audience has seen throughout the play. Contextualizing himself in this fashion, Paul becomes an exemplum in his own sermon, explaining how, at the literal level, he was a proud man whom God humbled and transformed to be a benefactor of Christians.

The second division of Paul's sermon continues to juxtapose meekness with pride, but here we understand this juxtaposition through Christ's personal experience:

'Lern at myself, for I am meke in hart'-

Owur Lorde to hys seruantys thus he sayth,

'For meknes I sufferyd a spere at my hart;

Meknes all vycys anullyth and delayeth;

Rest to soulys ye shall fynd in fayth:

"Discite a me quia mitis sum et corde humilis,

Et invenietis requiem animabus vestris". 32

So owur Sauyour shewyth vs exampls of meknes,

Thorow grace of hys goodnes mekly vs groundys.

Trwly yt wyll vs saue fro pe synnes sekenes,

For Pryde and hys progeny mekenes confoundys. 
Since the first division highlights Paul's experience, when the second division leads with 'Lern at myself, for I am meke in hart', the expected referent is Paul. Yet the following lines reveal that Christ's meekness is what destroys vice, and so Christ's example of sacrifice for humankind complements and strengthens Paul's experience, granting validity to Paul's internal change by drawing a parallel to the initial source of Christian meekness in Christ. By acting in imitation of Christ, Paul presents himself as an exemplum of imitatio Christi: just as he imitates Christ by humbling himself, so will his auditors imitate Christ if they do the same. This imitatio Christi trope captures the imitative essence of hagiography and reveals Paul's allegorical interpretation of his actions, showing how he molds Christ's humility to himself. Imitating Christ in this manner strengthens Paul's commitment to emptying himself of his former pride, as he now constitutes his selfhood through Christ instead of through himself.

Whereas the first two divisions take the personal experience of individuals into account, the third division presents a broader examination of how sin affects the body in general. This move allows Paul to extrapolate the ideas of meekness about which he has been speaking and apply them to the members of the audience. The experiences of his body and Christ's body are extraordinary, but these experiences have quotidian expressions as well, expressions that the audience must recognize if it is to avoid falling into sin through the temptation of the flesh. Earlier in his sermon, Paul employed imagery of the tree of vices to tell the audience to

... drede alway synne and folye

Wrath, enuy, coutytys, and slugyshnes;

Exeunt owt of thy sy3t glotony and lechery 33

Vanyte and vayneglory, and fals idylnes-

Thes be the branchys of all wyckydnes.

Who pat in hym thes vyces do roote,

He lackyth all grace, and bale ys pe boote.

Advising the members of the audience to rid themselves of vice, Paul essentially asks them to empty their bodies of 'synne and folye' as he has. Paul connects the actions of his body to those of the audience through his rhetoric, explaining to them how to experience the transformation he has undergone. What is more, Paul's rhetoric achieves this connection meta-theatrically: by using the verb 'Exeunt' — a common stage direction meaning 'They exit' to tell the audience to banish these vices 'owt of [its] sy3t', Paul's language 
figures the body as a sort of stage on which vice acts. Indeed, drawing on the performance of his own body, as Paul moves into his third division, he stresses how pride leads the body to other vices, focusing particularly on the sin of lechery and its connection to speech:

Fro sensualyte of fleshe, thyself loke pou lede;

Vnlefully therin vse not thy lyfe!

Whoso therin delyteth, to deth he must nede.

It consumyth nature, the body sleyth wythowt knyf;

Also yt styntyth nott but manslawter and stryf.

'Omnis fornicator aut immundus non habet hereditatem Christi':34

Non shall in heuyn posses that be so vnthryfty!

Fle fornycac[y]on, nor be no letchour,

But spare your speche, and spek nott theron:

'Ex habundancia cordis os loquitur'. 35

Who movyth yt oft, chastyte louyth non;

Of pe hartys habundans, pe tunge makyth locucyon.

What manys mynde ys laboryd, therof yt spekyth-

That ys of suernes, as Holy Scryptur tretyth.

The first of these two stanzas establishes that fornication, in particular, prevents the receipt of Christ's inheritance, or 'hereditadem Christi', as the biblical citation from Eph. 5:5 confirms. Paul's next stanza more fully explicates how he interprets 'fornycac[y]on' and lecherous behaviour, 'be no letchour': these certainly are sins of the body, but Paul locates their expression not in bodily lust but in bodily speech: 'spare your speche, and spek nott theron' (559, my emphasis). Paul stresses the role of words in lascivious behaviour, confirming through his quotation of Matt. 12:34 that the mouth, 'os', is the source of chaste and unchaste behavior: he 'Who movyth yt oft, chastyte louyth non'. Fornication and lechery are sins of the mouth that result from the 'locucyon' of 'pe tunge' and speech.

Paul continues to emphasize the mouth as the source of lechery and chastity as he offers the conclusion of his sermon:

Wherfor I reherse thys wyth myn owyn mowthe:

'Caste viuentes templum Dei sunt'. ${ }^{36}$

Kepe clene your body from synne vncuth;

Stabyll your syghtys, and look ye not stunt,

For of a sertaynte I know at a brunt, 
'Oculus est nuncius peccati-'37

That the Iey ys euer pe messenger of foly.

Paul demonstrates how his mouth has become a source of chaste living when he cites the commonplace expression 'Caste viuentes templum Dei sunt' [They who live chastely are the temple of God]. By rehearsing these words with his mouth, Paul connects his body to the experience of repentance that he has undergone; he also recalls the 'spech' for which he prayed at his sermon's outset (507). This gesture reminds the audience that the specific source of Paul's sin was the bombastic boasts of his mouth, and that through learning humility and preaching God's word by emptying himself and letting God provide the speech, Paul has reformed that sin of pride from which his mouth previously suffered. In his third division, Paul advises the audience to avoid sin by highlighting the snares of the flesh from which he himself has suffered. Thus Paul offers a tropological interpretation of himself, presenting his casting off of sin as a model to those who listen to him. Paul's conclusion emphasizes the moral behaviour of the body, reminding the audience, with a citation of John 9:41, to have steadfast vision, for 'Oculus est nuncius peccati' [The eye is the messenger of sin] (570). Like pride, the root of the tree of vices, the eye is the initial source tempting the body to sin. Paul therefore skillfully presents the same idea of falling into sin at the beginning and end of his sermon, developing it twice through the different bodily images of the mouth/speech and the eye.

\section{Poeta and Paul}

The Conversion of St Paul externalizes the internal and cognitive process of sermon construction in order to make maximum rhetorical effect of Paul's conversion. Paul executes this process by delivering a sermon that makes the internal procedure Poeta describes external to Paul and visible to the audience so that it experiences and understands his transformation into a Christian preacher. Paul's conversion is the hinge on which the moral success of St Paul depends, and the relationship that the playwright construes between Poeta and Paul brings the play's didacticism to fruition. Even though Poeta and Paul start the play with different relationships to rhetorical control, by its conclusion, the mutual source of their rhetorical empowerment is the Lord. Poeta's meta-rhetorical commentary suggests that the play, like a sermon, depends on the bestowal of God's grace for its moral to reach the audience. 
The play therefore moves towards a greater acknowledgement of God's agency in its rhetorical success as it progresses: yielding agency to God creates a more genuine selfhood which in turn conveys a more genuine agency upon the self, who, in this play, is the preacher. Poeta, for instance, appears powerless before the audience when the play starts because of his indirect approach to rhetorical invention, while Paul actually is rhetorically powerless when he introduces himself. As the play develops, each character changes his relationship to rhetoric, Poeta increasingly asserting his rhetorical dominance through the direct approach and Paul penitently emptying himself by withdrawing his bombastic words to become God's servant. When the play ends, both Poeta and Paul preach as mediators empowered by the Lord.

In spite of their mutual roles as mediators, the balance of power between Poeta and Paul remains uneven when the play concludes: Poeta asserts interpretative control over Paul despite the rhetorical deference that his last stanza grants because Poeta controls the interpretation of Paul's name. Although Saul becomes Paul after his conversion, quite strikingly this change does not register in the play's nomenclature. Neither the speech prefixes in the manuscript nor the characters' dialogue in the play acknowledge that Saul has become Paul. Despite his changed character, Paul is called 'Saul' after his conversion. Indeed, after the delivery of his sermon in the third episode, Paul says to an inquisitive priest: 'Yes, sertaynly, Saule ys my proper name' (579); and, after his sermon, Paul is addressed as Saul seven times, five times by characters in the play $(572,579,591,601,635)$, and twice by Poeta $(649$, 653). Even Poeta denies Paul the new identity that his conversion produces during the play, saying, in the stanza after his baptism: 'Thus Saule is conuertyd' (346). Yet, Poeta calls Saul 'Paul' twice before his conversion, once apiece in the stanzas opening the first and second episodes: 'The conuersyon of Seynt Paule' (10) and 'Saynt Poullys couercyon' (167) is the repeated subject of the play.

The retention of Saul's name may reflect the playwright's desire to maintain biblical accuracy, as Saul converts in chapter 9 of the Acts of the Apostles but is not called Paul until chapter 13:9; 38 or, as Matthew Hansen suggests, the name Saul may relieve the tension of the dramatic portrayal of the play's baptism: taking the name 'Paul' would risk making the baptism that Saul receives appear like the legitimate execution of the sacrament (309-38). ${ }^{39}$ The playwright's decision to suppress the name 'Paul' — the most obvious external rhetorical marker of Saul's conversion - suggests the importance of Poeta's shift from an indirect use of rhetorical invention in the first episode 
to a direct approach in the second and third episodes. St Paul must posit more interpretative power in Poeta as it progresses, because, by telling the audience how to understand what it sees - that it in fact sees Saul and not Paul - Poeta provides the reassurance that what the play offers spectators is a representation of the baptismal sacrament and not the sacrament itself. Poeta's employment of rhetorical invention intentionally waxes to force the audience's interpretative ability to wane so that no confusion results from Saul's conversion and baptism. Thus, while Saul's character is stable in the first episode, Poeta allows the audience the appearance of interpretative control, but as soon as Saul's conversion starts in the second episode and his baptism brings his character under examination, Poeta restricts the audience's interpretation, completely overtaking the role of interpreter in the third episode after Paul's baptism. The movement of Poeta's rhetorical invention from the indirect to the direct approach mitigates the potential effect of Paul's instability as a character, providing the underlying rhetorical frame for Paul's preaching so that the content of his sermon can convey a credible thematic and didactic message. The playwright therefore aligns preaching's rhetorical principles with its execution, exposing how Poeta's meta-rhetorical perspective and contributions produce the successful staging of Paul's conversion and sermon.

By uncovering the thematic construction of Paul's sermon and illuminating Poeta's engagement with rhetorical invention, this article demonstrates how St Paul both appropriates late medieval preaching theory and repurposes that theory for dramatic ends. St Paul's intentional integration of the sermonic and dramatic offers a new lens with which to evaluate this play, a lens that blurs generic distinctions by bringing into sharper focus how performance communicates moral lessons, the mutual goal of the sermon and drama. The moral value of the medieval sermon often obscures its other functions, that is, that the sermon was (and for some, still is) a popular type of entertainment. What is more, the thematic sermon, with its several parts and divisions, is itself a script — not dissimilar to a play — that guides the delivery of its speaker's words and the overall performance of its text. Used precisely to entertain in this play, Paul's preaching affirms the performative merit of the sermon, revealing that its form was accessible to a broad array of people, such as those comprising the members of a play-going audience. This reality suggests that there is a certain connoisseurship of performance, and a certain delight derived from recognizing — even if one did not know the precise Latin terminology of every rhetorical move in a sermon - how the 
delivery of preaching rhetoric is performative. Indeed, the St Paul playwright demonstrates just how compatible sermon and play are as he integrates both in his drama, achieving a dynamic interdependence between preaching rhetoric and dramatic narrative throughout this moral performance. Paul's sermon and Poeta's invention both reinforce Paul's ethical change in character, blending each of these preaching techniques so thoroughly with St Paul's dramatic structure and episodic plot narrative that the result of trying to divorce one from the other would upset the thematic cohesion of the play as a whole. Poeta's and Paul's parallel intentions to model humility and to educate the audience emerge precisely because of the play's integrated form, and failing to acknowledge this integration runs the risk of impairing $S t$ Paul's ultimate didactic success, which is to place Poeta and Paul in dialogue through the complementary literal, allegorical, and tropological scriptural messages that each communicates throughout the play.

\section{Appendix 1: The Organization of Paul's Thematic Sermon}

Theme: 'pryde' (511)

Confirmed by the authority from Eccles. 10:13, 'Initium omnium peccatorum su[per]bia est' (514)

Protheme: 'humylyte' (517)

Confirmed by the authority from Luke 14:11 and 18:14, 'Omnis qui se exaltat humiliabitur' (520)

Restatement of the Theme: 'pryde' (523)

First Division: Paul speaks from his own personal experience

Confirmed by the authority from Rom. 11:20, 'Noli tibi dico in altum sapere sed time' (528)

Second Division: Paul speaks about the experience of the Lord Confirmed by the authority from Matt. 11:29, 'Discite a me quia mitis sum et corde humilis, / Et invenietis requiem animabus vestris' (542-3)

Third Division: Paul speaks about the experience of the body in sin Confirmed by the authority from Eph. 5:5, 'Omnis fornicator aut immundus non habet hereditatem Christi' (555), and by an authority from Matt. 12:34, 'Ex habundancia cordis os loquitur' (560) 
Conclusion: Paul locates the sin of pride in the mouth Confirmed by the commonplace expression, 'Caste viuentes templum Dei sunt' (566), and by an authority from John 9:41, 'Oculus est nuncius peccati' (570)

\section{Notes}

I would like to thank Martin Camargo and Robert W. Barrett Jr. for reading and commenting upon earlier versions of this article.

1 Extant only in ms Digby 133, The Conversion of St Paul is a difficult play to date. Based on watermarks and paleographical evidence, scholars assign the composition of the main text to approximately 1500 and the added devil scene to the 1550 s (D.C. Baker and J.L. Murphy, 'MS. Digby 133: Scribes, Dates, and Early History', Research Opportunities in Renaissance Drama 10 (1967), 153-66. The addition of the devil scene suggests that performances of St Paul persisted across the late medieval / early modern divide, allowing for productions both before and during the Reformation in England. For discussions of possible performances in the Reformation, see John Coldewey, 'The Digby Plays and the Chelmsford Records', Research Opportunities in Renaissance Drama 18 (1975), 103-21; Heather Hill-Vasquez, 'The Possibilities of Performance: A Reformation Sponsorship for the Digby Conversion of St. Paul', Records of Early English Drama 22 (1997), 2-19; and Heather Hill-Vasquez, Sacred Players: The Politics of Response in the Middle English Religious Drama (Washington DC, 2007), 51-74.

2 'Staging Conversion: the Digby Saint Plays and The Book of Margery Kempe', Samantha J.E. Riches and Sarah Salih (eds), Gender and Holiness: Men, Women and Saints in Late Medieval Europe (London, 2002), 121-34, here cited from 128, doi: http://dx.doi.org/10.4324/9780203994603.

3 Salih, 'Staging Conversion', 129. Many scholars discuss the significance of Saul changing his clothes. For an overview, see Chester N. Scoville, 'The Hood and the Basket: Image and Word in the Digby Conversion of St. Paul', Research Opportunities in Renaissance Drama 41 (2002), 157-67 and Clifford Davidson, 'Violence and the Saint Play', Studies in Philology 98 (2001), 292-314.

4 Citations of The Conversion of St Paul are from The Late Medieval Religious Plays of Bodleian MSS. Digby 133 and E Museo 160, Donald C. Barker, John L. Murphy, and Louis B. Hall Jr. (eds), EETS 285 (Oxford, 1982).

5 The majority of scholars who address Saul's change of name to Paul do so only cursorily, claiming no more than that the change occurs. Chester Scoville, Saints 
and the Audience in Middle English Biblical Drama (Toronto, 2004), 91, however, notes the opposite: 'although the play is called the "The conuersyon of Seynt Paule" (9), the character does not change his name from Saul to Paul upon his conversion, contrary to popular expectation'.

6 For information on the thematic sermon, see Marianne G. Briscoe, Artes Praedicandi, L. Genicot (ed.), Typologie des Sources du Moyen Âge 61 (Turnhout, 1992), 1-68.

7 See James J. Murphy, Introduction, Three Medieval Rhetorical Arts, (Berkeley, 1971), ix, for the five rhetorical principles incorporated from classical rhetoricians that inform medieval preaching: 'inventio (finding material), dispositio (arranging of it), elocutio (putting words to invented material), pronuntiatio (physical delivery), and finally memoria (retention of ideas, words, and their order)'. St Paul engages with the other four principles only tangentially. The playwright's most substantial use of them is dispositio, which he incorporates by using Poeta to divide and organize the material found in Acts of the Apostles into three distinct episodes in his play.

8 Scholars have argued that Poeta's interventions constitute a frame in sundry ways. For Victor I. Scherb, 'Frame Structure in The Conversion of St. Paul', Comparative Drama 26 (1992), 124-39, they set the play's devotional tone in an opening prayer; for Salih, 'Staging Conversion', 126, they reassure the audience of the stability of a character made unstable through the process of conversion; for Scoville, 'On Bombshells and Faulty Assumptions: What the Digby Conversion of Saint Paul Really Did with the Acts of the Apostles', David N. Klausner and Karen Sawyer Marsalek (eds), 'Bring Furth the Pagants': Essays in Early English Drama Presented to Alexandra F. Johnston (Toronto, 2007), 204, they validate the play's authority through citations of the bible and the Acts of the Apostles especially; and finally, for David L. Jeffrey, 'English Saints' Plays', Neville Denny (ed.), Medieval Drama (London, 1973), 74, they embody an historical moment of unrest before and during the Reformation in which the accuracy of biblical interpretation was contested.

9 The total number of Poeta's appearances can vary depending on directorial choices. A marginal note in the manuscript makes Poeta's appearance to conclude the first episode optional, meaning he could appear five or six times in a given performance, five if he does not return to close the first episode and six if he does. Scholars debate the staging of the play as follows: F.J. Furnivall argued that the play was staged on pageant wagons that moved to various locations in the introduction to his edition of the play: The Digby Plays with an Incomplete 'Morality' of Wisdom, Who is Christ, EETS es 70 (London, 1896). In more recent years, scholars have contested Furnivall's interpretation, arguing instead for a place-and-scaffold model of performance. See Mary del Villar, 'The Staging of The Conversion of St. Paul', Theatre Notebook 25 (1970-1), 64-8; Glynne Wickham, 'The Staging of Saint Plays in England', Sandra 
Sticco (ed.), The Medieval Drama (Albany, 1972), 99-119; and Raymond J. Pentzell, 'The Medieval Theatre in the Streets', Theatre Survey 14 (1973), 1-21, doi: http:// dx.doi.org/10.1017/s0040557400005020.

10 'King of glory'. All Latin translations are my own.

11 'Acts of the Apostles'.

12 Robert of Basevorn, 'The Form of Preaching', Leopold S. Krul, O.S.B., (trans.), James J. Murphy (ed.), Three Medieval Rhetorical Arts (Berkeley, 1971), 148-50. Manuscript British Museum Royal 18 B. xxiii provides several parallel locutions. See, for instance, Woodburn O. Ross (ed.), Middle English Sermons: Edited from British Museum MS. Royal 18 B. xxiii, EETS os no 209 (London, 1940), 46: Sermon 9 addresses its auditors as 'Worshippull bretheren and susteren', and begins with this prayer: 'The [helpe] and pe grace of almyghty God thorowght poz besechyng of ys blessed modur and mayden, Oure Ladye Seynt Mary, be with vs now at oure begynnynge, helpe vs and spede vs in all oure lyvynge, and brynge vs to pat blis pat neuer shall haue endynge. Amen'.

13 H. Leith Spencer, English Preaching in the Late Middle Ages (Oxford, 1993), 111, doi: http://dx.doi.org/10.1093/acprof:oso/9780198112037.001.0001. Sermon 48 from British Museum Royal 18 B. xxiii, in Ross (ed.), Middle English Sermons, 314, provides an example of the word 'process', used in this sermon as the preacher offers his division of the parts, a rhetorical move that provides the points of proof for a theme: 'Frendes, for a processe ze shull vndirstond pat I fynde in holy writt iij commynges of oure Lord; the first was qwen pat he com to make man; the second was qwhen he com to bie man; and pe iij shall be qwen he shall com to deme man'.

14 Cicero, De Inventione, H.M. Hubbell (trans.), Cicero: De Inventione; De Optimo Genere Oratorum; Topica (Cambridge, MA, 1960), 43.

15 Clare A. Waters, Angels and Earthly Creatures: Preaching, Performance, and Gender in the Later Middle Ages (Philadelphia, 2004), 31-56, doi: http://dx.doi .org/10.9783/9780812204032.

16 Beverly Mayne Kienzle, 'Medieval Sermons and Their Performance: Theory and Record', Carolyn Muessig (ed.), Preacher, Sermon, and Audience in the Middle Ages (Leiden, 2002), 116.

17 Salih, 'Staging Conversion', 204.

18 Hill-Vasquez, Sacred Players, 66.

19 Because Poeta's prologues and epilogues repeatedly return to the question of how much interpretative authority to grant an audience, St Paul continually negotiates its Catholic and Protestant identities and is able to support both simultaneously. Catholic and Protestant readings of the play alike emphasize the centrality of using and understanding scripture to promote belief. The difference lies in who does the 
work of analysis to reach scripture's understanding: in a Catholic reading, a preacher would interpret the scripture for his auditors, whereas a Protestant reading enables the individual to interpret the meaning for him/herself. At the conclusion of the first episode, Poeta's use of insinuation means that he does not aid the audience's interpretation, a rhetorical posturing akin to Protestantism's scriptural practice but one that also preserves Catholicism's potential for auditors to deny themselves a preacher's necessary scriptural intervention. This stanza in the play's second episode - insistent about the need for unidentified masters who are lettered — therefore highlights particularly well how Poeta's prologues and epilogues maintain the play's Catholic and Protestant possibilities by continually obscuring who interprets scripture. The ongoing question as to the audience's ability to interpret scripture successfully with or without the assistance of a preacher foregrounds St Paul's initial composition as a Catholic play (wherein assistance would be needed) and later production as a Protestant drama (wherein assistance would not be needed), and perhaps helps to explain why this play survived the Reformation in England intact.

20 Scoville, 'On Bombshells and Faulty Assumptions', 201-7.

21 This differentiation between lettered and unlettered audience members is one that concerned writers of medieval preaching manuals, and so represents a common concern among preachers. For example, in his Ars Concionandi, Pseudo-Bonaventure discusses different types of thematic sermon divisions that are appropriate for lay and clerical audiences, offering 'three types of division suitable for the laity: sufficientia, interrogativa, and vulgariza' and 'two principle sorts of internal division for the clergy: per verba and per causualia' (Briscoe, Artes Praedicandi, 34). Despite this distinction, the form of the thematic sermon itself is clearly appropriate for a wide variety of audiences. Even though it may not always have been executed with all of its rhetorical flourishes, the thematic sermon became a ubiquitous form, thanks mostly to its spread by the mendicant orders (Ibid, 28-9). Writers of preaching manuals understood it to be a universally accessible form, as the sample sermons witness in Alan of Lille's seminal preaching manual, the Summa de Arte Praedicatoria: 'Alan's range of audiences suggests that he sees no need to differentiate among various forms of sermon appropriate for this diversity of hearers [soldiers, orators or advocates, princes or judges, cloistered religious, priests, married people, widows, virgins, and finally ... those whose souls need awakening]; he implies that the thematic sermons work for all' (Ibid, 25). Lay and clerical audiences alike recognized the cadences of the thematic sermon.

22 'Lifting him in a basket they sent him out'.

23 'Truly'.

24 'Let heaven rejoice with praises!' 
25 Scherb, 'Frame Structure', 135.

26 A thematic sermon proposes to teach its audience by isolating a sentence, phrase, or word, typically from the bible, as a theme, and then expands upon its meaning through a series of rhetorical moves. In practice, these rhetorical moves can contain much variation, but a thematic sermon's principle components tend to develop according to the following general scheme: protheme, restatement of the theme, introduction, division of the parts, supporting subdivisions, and conclusion. For more detailed information about the construction of thematic sermons, see Briscoe, Ars Praedicandi, 1-68.

27 'The beginning of all sins is pride'.

28 'Anyone who praises himself will be humiliated'.

29 Robert of Basevorn, 'The Form of Preaching', 133-42.

30 Ibid, 148-50.

31 'To you I say do not know high things but fear'.

32 'Learn from me because I am gentle and humble in heart, / And you will find rest for your souls'.

33 'Exit'.

34 'Every fornicator or sinner does not hold the inheritance of Christ'.

35 'The mouth speaks from the abundance of the heart'.

36 'They who live chastely are the temple of God'.

37 'The eye is the messenger of sin'.

38 Scoville, Saints and the Audience, 91.

39 'Dancing in the Shadows: Ritual, Drama, and the Performance of Baptisms in the Digby Conversion of St. Paul and Philip Massinger's The Renegado', Quidditas 30 (2009), 69. 